\title{
Description of two new species of the genus Heterochelamon Türkay \& Dai, 1997 (Crustacea: Decapoda: Brachyura: Potamidae), from southern China
}

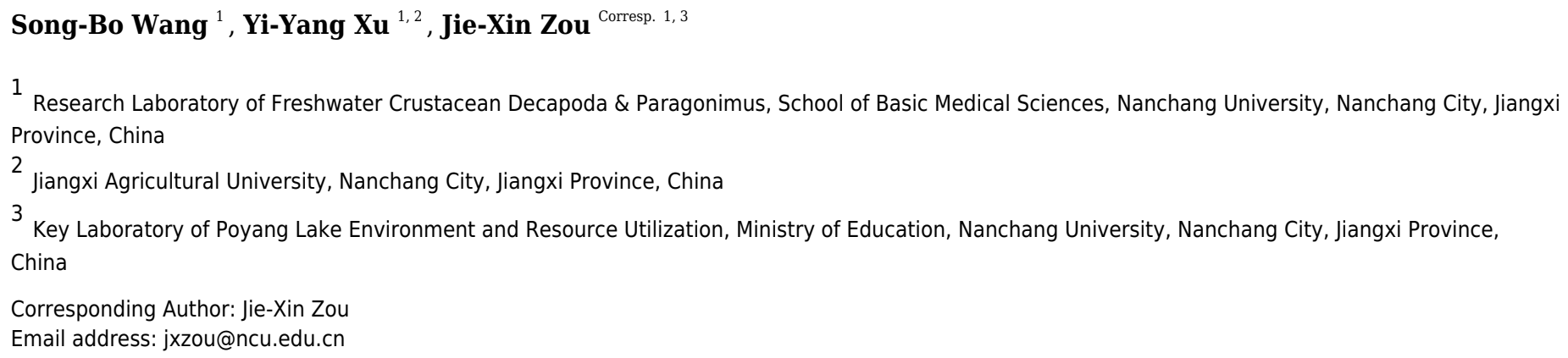

This study describes two new species of freshwater crab of the genus Heterochelamon Türkay \& Dai, 1997 from southern China, $H$. huidongense from Guangdong Province and $H$. jinxiuense from Guangxi Zhuang Autonomous Region. The two new species can be differentiated from congeners by characters derived from the shape of the epibranchial tooth, external orbital angle, cheliped proportions and structure of the male first gonopod. The present study brings the number of Heterochelamon species to seven. We used the mitochondrial 16S rRNA gene for a molecular analysis and the results are consistent with the morphological features that support the recognition of two new taxa. 


\section{Description of two new species of the genus}

2 Heterochelamon Türkay \& Dai, 1997 (Crustacea:

3 Decapoda: Brachyura: Potamidae), from southern

4 China

Song-Bo Wang ${ }^{1}$, Yi-Yang $\mathrm{Xu}^{1,2}$, Jie-Xin Zou ${ }^{1,3}$

${ }^{1}$ Research Laboratory of Freshwater Crustacean Decapoda \& Paragonimus, School of Basic Medical Sciences, Nanchang University, Nanchang City, Jiangxi Province, China

${ }^{2}$ Jiangxi Agricultural University, Nanchang City, Jiangxi Province, China

${ }^{3}$ Key Laboratory of Poyang Lake Environment and Resource Utilization, Ministry of Education, Nanchang University, 1299 Xuefu Avenue, Nanchang City, Jiangxi Province, China

Corresponding Author:

Jie-Xin Zou ${ }^{1}$

1299 Xuefu Avenue, Nanchang City, Jiangxi Province, People's Republic of China

Email address:jxzou@ncu.edu.cn

\section{Abstract}

This study describes two new species of freshwater crab of the genus Heterochelamon Türkay \& Dai, 1997 from southern China, $H$. huidongense from Guangdong Province and $H$. jinxiuense from Guangxi Zhuang Autonomous Region. The two new species can be differentiated from congeners by characters derived from the shape of the epibranchial tooth, external orbital angle, cheliped proportions and structure of the male first gonopod. The present study brings the number of Heterochelamon species to seven. We used the mitochondrial 16S rRNA gene for a molecular analysis and the results are consistent with the morphological features that support the recognition of two new taxa.

\section{Introduction}

Freshwater crabs are found in the tropics and subtropics in most parts of the world, occurring in aquatic habitats ranging from clear montane streams to lowland rivers and even in caves or tree holes (Dai, 1999; Ng, Guinot \& Davie, 2008). Southern China, where mountains and rivers are abundant, provides a multitude of habitats for a large number of species and the large numbers of new taxa reported in recent years indicate that research on this group remains in a "discovery" phase (Yeo et al., 2008; Zhu, Naruse \& Zhou, 2010; Naruse, Zhu \& Zhou, 2013; Huang, Mao \& Huang, 2014; Shih \& Do, 2014; Huang, Shih \& Mao, 2016; Huang, Shih \& Ng, 2017; Huang, Ahyong \& Shih, 2017; Ng, 2017; Huang, 2018; Huang, Shih \& Ahyong, 2018; Huang, Wong \& Ahyong, 2018; Wang, Huang \& Zou, 2019; Wang, Zhou \& Zou, 2019). 
Currently, the freshwater crabs distributed in China are represented by 49 genera in the families Potamidae Ortmann, 1896 and Gecarcinucidae Alcock, 1910 (Chu et al., 2018; Chu, Wang \& Sun, 2018; Huang, Shih \& Ahyong, 2018; Huang, Huang \& Shen, 2020). The potamid genus Heterochelamon was established by Türkay \& Dai (1997) to accommodate Potamon (Geothelphusa) purpureomanualis $\mathrm{Wu}, 1934$ (type species), theretofore assigned to Malayapotamon, and two new species, $H$. guangxiense and $H$. yangshuoense. Naruse, Zhu \& Zhou (2013) further described two new species, $H$. tessellatum and $H$. castanea. The five known species exclusively occur in Guangxi Zhuang Autonomous Region (Türkay \& Dai, 1997; Naruse, Zhu \& Zhou, 2013).

In 2011, we collected specimens of a Heterchelamon species from Jinxiu, Guangxi, but the crabs were not identified at the time. It was not until 2018 that our research team identified the specimens as belonging to an undescribed species. In 2019, freshwater crab enthusiast Jia-Ming Tian collected some dark colored freshwater crabs from Huidong, Guangdong. We subsequently collected specimens of this species and found that they belong to another new species of Heterochelamon. We herein describe two new species of Heterochelamon, including the one from Guangdong Province, representing the first member of the genus from outside of Guangxi.

To study the phylogenetic relationships of species within Heterochelamon, we used the mitochondrial 16S rRNA gene data of four species from this genus, including the two new species reported in this paper. Molecular data supports the recognition of the two new species and their assignment to Heterochelamon.

\section{Material \& Methods}

Specimens were collected by Song-Bo Wang, Yi-Yang Xu, Jia-Ming Tian and Xi-Jiao Wei; preserved in $95 \%$ ethanol and deposited in the Department of Parasitology of the Medical College of Nanchang University, Jiangxi, China (NCU MCP), National Tropical Disease Research Center, Shanghai, China (TDRC). The abbreviations G1 and G2 are used for the male first gonopod and second gonopod, respectively. Carapace width and length are reported in millimeters. The terminology used primarily follows that of Dai (1999), Naruse, Zhu \& Zhou (2013) and Davie et al. (2015).

Muscle tissue was extracted from the ambulatory legs and chelipeds, and total genomic DNA was extracted from the tissues using the Omega Tissue Kit following the manufacturer's protocol. Mitochondrial 16S rRNA gene sequences were obtained by PCR amplification with the primers 1471 (5'-CCTGTTTANCAAAAACAT-3') and 1472 (5'AGATAGAAACCAACCTGG-3') (Shih et al., 2004). The PCR procedure was as follows: 33 cycles of denaturation for $50 \mathrm{~s}$ at $94^{\circ} \mathrm{C}$, annealing for $40 \mathrm{~s}$ at $52^{\circ} \mathrm{C}$, and extension for $1 \mathrm{~min}$ at $72^{\circ} \mathrm{C}$, followed by a final extension for $10 \mathrm{~min}$ at $72^{\circ} \mathrm{C}$. Sequences were obtained by automated sequencing (ABI3730 automatic sequencer).

Sequences were aligned using MAFFT vers.7.355 (Nakamura et al., 2018) based on the GINS-I method and the selection of conserved regions with Gblocks 0.91b (Castresana, 2000). $\mathrm{GTR}+\mathrm{I}+\mathrm{G}$ was the best fit model for the sequence evolution of the $16 \mathrm{~S}$ dataset, as determined 
79

80

81

82

83

84

85

86

87

88

89

90

91

92

93

94

95

96

97

98

99

100

101

102

103

104

105

106

107

108

109

110

111

112

113

114

115

116

117 with MrModeltest vers.2.2 (Nylander, 2005) and then selected based on the Akaike information criterion (AIC). MrBayes vers.3.2.6 (Ronquist et al., 2012) was used to construct a Bayesian inference (BI) tree. Four Markov chain Monte Carlo (MCMC) chains were run for 2,000,000 generations, with samples stored once every 1000 generations, discarding the first $25 \%$ as burnin. Tracer vers.1.6 (Rambaut et al., 2014) was used to check effective sample size (ESS) values (all of greater than 200). Simultaneously with the BI analysis, we used MEGA vers.X.0 (Kumar et al., 2018) to select the best evolutionary model for maximum likelihood (ML) analysis, which was the $\mathrm{HKY}+\mathrm{I}+\mathrm{G}$ model based on the Bayesian information criterion (BIC). The ML tree was built after 1000 bootstrap replicates by using MEGA vers.X.0 (Kumar et al., 2018).

The electronic version of this article in portable document format will represent a published work according to the International Commission on Zoological Nomenclature (ICZN), and hence the new names contained in the electronic version are effectively published under that Code from the electronic edition alone. This published work and the nomenclatural acts it contains have been registered in ZooBank, the online registration system for the ICZN. The ZooBank LSIDs (Life Science Identifiers) can be resolved and the associated information viewed through any standard web browser by appending the LSID to the prefix http://zoobank.org/. The LSID for this publication is: urn:lsid:zoobank.org:pub: F680C21E-0BED-4724-BA62-1174336F433F. The online version of this work is archived and available from the following digital repositories: Peer J, PubMed Central, and CLOCKSS.

\section{Results}

Systematics

\section{Family Potamidae Ortmann, 1896 \\ Heterochelamon Türkay \& Dai, 1997}

Heterochelamon huidongense n. sp. (Figs. 1-4)

urn:1sid:zoobank.org: act: 0F67FA91-6734-4800-9C03-76668635A1E2

Material examined. Holotype: male $(25.8 \times 23.1 \mathrm{~mm})(\mathrm{NCU}$ MCP 423601), Xinaobei Village (2255'14.59' 'N 114³3'51.85' 'E, 47 m asl.), Baihua Town, Huidong County, Huizhou City, Guangdong Province, coll. Song-Bo Wang, Yi-Yang Xu and Jia-Ming Tian, $6^{\text {th }}$ Jul. 2019. Paratypes: 3 males $(30.0 \times 25.8 \mathrm{~mm}, 26.2 \times 23.1 \mathrm{~mm}, 21.3 \times 18.6 \mathrm{~mm})(\mathrm{NCU}$ MCP 423602, TDRC 002005, TDRC 002006) and 2 females $(26.1 \times 23.5 \mathrm{~mm}, 20.6 \times 18.5 \mathrm{~mm})(\mathrm{NCU}$ MCP 423603, TDRC 002007), same data as holotype. Others: 5 males $(29.6 \times 25.4 \mathrm{~mm}, 26.4 \times 23.5$ $\mathrm{mm}, 25.1 \times 22.3 \mathrm{~mm}, 28.4 \times 24.5 \mathrm{~mm}, 21.3 \times 18.9 \mathrm{~mm}$; NCU MCP 423606, NCU MCP 423607, NCU MCP 423608, NCU MCP 423609, NCU MCP 423610) and 2 females $(21.1 \times 19.1 \mathrm{~mm}$, $14.5 \times 12.5 \mathrm{~mm}$; NCU MCP 423612, NCU MCP 423613), same data as holotype.

PeerJ reviewing PDF | (2020:04:48437:1:1:NEW 26 Jun 2020) 
118 Comparative material. Heterochelamon yangshuoense Türkay \& Dai, 1997: Holotype, male,

119

120

121

122

123

124

125

126

127

128

129

130

131

132

133

134

135

136

137

138

139

140

141

142

143

144

145

146

147

148

149

150

151

152

153

154

155

156

157

IZCAS CB 05102, Yangshuo County, Guilin City, Guangxi Zhuang Autonomous Region, $8^{\text {th }}$ May 1975. H. guangxiense Türkay \& Dai, 1993: Holotype, male, IZCAS CB 01336, Guangxi Zhuang Autonomous Region, May 1974. H. purpureomanualis Türkay \& Dai, 1997: not holotype, male, IZCAS CB, Yao Mountain, Xiuren Town, Lipu County, Guilin City, Guangxi Zhuang Autonomous Region, 1938. H. tessellatum Naruse, Zhu \& Zhou, 2013: Holotype, male, NCU MCP 2012.0003, Dong Men Zhuang, Shuangluo Village, Sanli Town, Shanglin County, Guangxi Zhuang Autonomous Region, 14 ${ }^{\text {th }}$ Aug. 2006, Paratypes, 1 male, NCU MCP 2012.0004, 1 female, NCHUZOOL 13572, same data as holotype. H. castanea Naruse, Zhu \& Zhou, 2013: Holotype: male, NCU MCP 2012.0001, Lituan Village, Baiming Town, Liujiang County, Liuzhou City, Guangxi Zhuang Autonomous Region, Aug. 2006, Paratype: 1 female, NCU MCP 2012. 0002, same data as holotype.

Diagnosis. Carapace subquadrate, dorsal surface covered with scattered minute pits, regions not clearly demarcated. External orbital angle triangular, sharp; postorbital cristae inconspicuous. Epibranchial tooth very sharp, distinct. Anterolateral margin cristate. Suborbital, pterygostomial regions smooth. Median lobe of epistome posterior margin protruded slightly. Third maxilliped exopod exceeding posterior margin of merus, with long slender flagellum. Chelipeds unequal, cutting edges of finger of larger cheliped with blunt teeth, with narrow gap when fingers closed. Ambulatory legs slender. Male telson triangular, lateral margins slightly concave. Female vulva located at middle of sternite 6. G1 terminal segment flat and medially bent, not tapered distally, apex rounded, reaching pleonal locking tubercle on mid length of sternite 5 but not exceeding sternites $4 / 5$ suture.

Description. Carapace subquadrate, width about 1.1 times as length $(n=13)$, regions not clearly demarcated; dorsal surface convex longitudinally, smooth (Figs. 1A, 3A). External orbital angle triangular, sharp, separated from anterolateral margin by U-shaped notch; postorbital cristae inconspicuous, postfrontal lobe slightly convex, separated from each other; cervical groove indistinct; $\mathrm{H}$-shaped gastric groove indiscernible (Figs. 1A and 3A). Epibranchial tooth very sharp, distinct; anterolateral margin cristate, straight, lined with 7-8 granules, shorter than posterolateral margin; posterolateral surface smooth (Figs. 1A, 3A). Frontal, supra-, infraorbital margins cristate, lined with indistinct granules; suborbital, pterygostomial regions smooth, with a few round granules (Fig. 1B). Epistome posterior margin distinctly cristate, median lobe low, triangular, lateral margins slightly sinuous (Fig. 1B).

Third maxilliped exopod exceeding posterior margin of merus, with long slender flagellum; merus about 1.2 times as broad as long, slightly depressed medially; ischium about 1.4 times as long as broad, with distinct median sulcus (Fig. 2B).

Male chelipeds unequal (Fig. 1A). Merus surface smooth without any pits; carpus with inner angle produced into strong spine, surface sparsely covered with pits (Figs. 1A). Cutting edges of larger cheliped fingers with row of large blunt teeth, with narrow gap when fingers

Peer) reviewing PDF | (2020:04:48437:1:1:NEW 26 Jun 2020) 
158

159

160

161

162

163

164

165

166

167

168

169

170

171

172

173

174

175

176

177

178

179

180

181

182

183

184

185

186

187

188

189

190

191

192

193

194

195

196

197

198

closed (Fig. 2A). Ambulatory legs slender; third legs longest when stretched laterally, fourth ambulatory leg propodus about 1.6 times as long as broad, slightly shorter than dactylus, with scattered thorn-like setae (Fig. 2E).

Male thoracic sternites 2/3 demarcated by distinct suture, sternites 3/4 demarcated by shallow groove (Fig. 2C). Male sterno-pleonal cavity deep, reaching anteriorly to mid-length of thoracic sternite 4; median groove between sternites 7/8 long (Fig. 2E). Male pleon triangular, somites 3-6 gradually decreasing in width, increasing in length in males; somite 3 widest; somite 6 trapezoidal, margins slightly oblique (Figs. 2D). Telson triangular with rounded apex, lateral margin slightly concave (Fig. 2C). Female pleon broadly ovate (Fig. 3B); vulva small, ovate, located at middle of sternite 6, opening inwards, posterior margin slightly bulged (Fig. 3C).

G1 slender; terminal segment flat, bent medially, not tapered distally, distal part rounded; exceeding pleonal locking tubercle on mid length of sternite 5, not reaching suture between sternites 4/5 (Figs. 4A-D, 2F). Distinct boundary between terminal segment and subterminal segment, latter length about 2.5 times as former, groove for G2 in ventral surface; G2 basal segment triangular, length about 2.1 times distal segment (Fig. 4).

Etymology. The species is named after the type locality, Huidong County, Huizhou City, Guangdong Province.

Distribution. The new species is known only from the type locality presently, Huidong County, Huizhou City, Guangdong Province, southern China.

Ecology. Specimens of the new species were collected at three sites along a river using fish cages or by hand (Figs. 5B, 5C). The water of the river is relatively clear, and the water flow is slow. The width of the river is approximately 1-3 meters and the depth is approximately 0.2-0.3 meters. The river bed is mainly sand and soil (Fig. 5E). There are many shrubs and low hills around the river, many households located dozens of meters away from the river and some vegetable gardens along the river (Fig. 5A). At one of the collection points, we also collected specimens of the gecarcinucid Somanniathelphusa sinensis H. Milne-Edwards, 1853 (Fig. 5D), which we believe coexists with the new species in the river.

Remarks. Compared to congeners, Heterochelamon huidongense n. sp. can easily be separated by its G1 not reaching sternites 4/5 suture in situ and terminal segment being medially bent (Figs. 2E and 4A, Table 1) (versus reaching sternites $4 / 5$ suture and straight in congeners, except H. tessellatum which has G1 that also does not reach the sternites $4 / 5$ suture but is strongly bent proximally), as well as a combination of characters: very sharp epibranchial tooth, triangular external orbital angle, slightly convex anterolateral margins (Fig. 1A), triangular male telson (Fig. 2C), and inward opening female vulva (Fig. 3C). For detailed differences between this new species and congeners, see Table 1.

Heterochelamon jinxiuense n. sp. (Figs. 5-8) 
199

200

201

202

203

204

205

206

207

208

209

210

211

212

213

214

215

216

217

218

219

220

221

222

223

224

225

226

227

228

229

230

231

232

233

234

235

236

237

Material examined. Holotype: 1 male $(24.6 \times 19.8 \mathrm{~mm})(\mathrm{NCU}$ MCP 342001), from Tongfu Village (2417'10.89'’ N 1155'17.28'’E, 267 m asl.), Toupai Town, Jinxiu Yao Autonomous County, Laibin City, Guangxi Zhuang Autonomous Region, coll. Xi-Jiao Wei, $8^{\text {th }}$ Jul. 2011. Paratypes: 3 males $(20.3 \times 15.8 \mathrm{~mm}, 15.8 \times 12.6 \mathrm{~mm}, 17.8 \times 14.8 \mathrm{~mm})(\mathrm{NCU}$ MCP 342002 , TDRC 002008, TDRC 002009) and 1 female $(12.9 \times 10.4 \mathrm{~mm})(\mathrm{NCU}$ MCP 342003), same data as holotype. Other: 1 male $(14.1 \times 11.4 \mathrm{~mm})(\mathrm{NCU}$ MCP 342006), same data as holotype.

\section{Comparative material. See for Heterochelamon huidongense n. sp.}

Diagnosis. Carapace trapezoidal, flat, surface covered with scattered minute pits. External orbital angle blunt, postorbital cristae, postfrontal lobe indiscernible. Epibranchial tooth blunt, distinct; anterolateral margin cristate, slightly convex. Suborbital, pterygostomial regions very smooth. Median lobe of epistome posterior margin distinctly protruding. Third maxilliped exopod with long flagellum. Chelipeds strongly unequal in adult males, surface smooth, lower cutting edge of major cheliped finger with very large, blunt teeth, with medium gap when fingers closed. Ambulatory legs slender. Thoracic sternites 2/3 demarcated by distinct deep suture, anterior part of sternite 3 convex. Male sterno-pleonal cavity deep, narrow. Male telson triangular, lateral margin straight. Female vulva reaching sternites 5/6 suture. Male G1 terminal segment rod-like, tapered distally, subdistal segment suddenly inwardly bent, reaching sternites $4 / 5$ suture.

Description. Carapace trapezoidal, flat, width about 1.3 times as length $(n=6)$, regions not clearly demarcated; dorsal surface slightly convex, covered with inconspicuous pits (Figs. 6A, 8A). External orbital angle blunt, separated from anterolateral margin by shallow notch; postorbital cristae inconspicuous, postfrontal lobe indistinct; cervical groove indistinct; H-shaped gastric groove indiscernible (Figs. 6A, 8A). Epibranchial tooth blunt, distinct; anterolateral margin cristate, slightly convex, lined with several granules, shorter than posterolateral margin; posterolateral surface smooth (Figs. 6A, 8A). Frontal and orbital margins cristate, lined with indistinct granules, supra-, infraorbital margins glazed; suborbital, pterygostomial regions very smooth, not covered with granules (Fig. 6B). Epistome posterior margin distinctly cristate, median lobe triangular, distinctly protruding, lateral margins almost straight (Fig. 6B).

Third maxilliped exopod exceeding posterior margin of merus, with slender flagellum; merus about 1.2 times as broad as long, with median depression; ischium about 1.4 times as long as broad, longitudinal median sulcus distinct (Fig. 7B).

Chelipeds strongly unequal in adult males (Fig. 7A). Merus surface smooth without any pits; carpus inner angle forming stout spine, surface not covered with pits (Fig. 1A). Cutting edge of larger cheliped fixed finger with large rounded teeth, movable finger cutting edge lined with several small teeth, with medium gap when fingers closed (Fig. 7A). Ambulatory legs slender; 
238 third legs longest, the fourth ambulatory leg propodus about 2.0 times as long as broad, equal to

239

240

241

242

243

244

245

246

247

248

249

250

251

252

253

254

255

256

257

258

259

260

261

262

263

264

265

266

267

268

269

270

271

272

273

274

275

276

277

dactylus in length (Figs. 6A, 7F).

Male thoracic sternites 2/3 demarcated by distinct deep suture, anterior part of sternite 3 convex, sternites $3 / 4$ suture discernible as shallow groove, sterno-pleonal cavity reaching imaginary line joining posterior third of cheliped coxae (Fig. 7C). Male sterno-pleonal cavity deep, narrow; median longitudinal groove between sternites 7/8 medium-length (Fig. 7E). Male pleon triangular, third somite widest; somite 6 trapezoidal; somites 3-6 gradually decreasing in width (Fig. 7D). Telson triangular with rounded apex, lateral margin slightly convex (Fig. 7D). Female vulva very small, ovate, reaching sternites $5 / 6$ suture, located at upper of sternite 6 (Fig. $8 \mathrm{~B})$.

Male G1 slender; terminal segment rod-like, almost straight, tapered distally; apex sharp, abruptly bent inwards subdistally; reaching beyond pleonal locking tubercle on mid length of sternite 5 , to suture between sternites $4 / 5$ (Figs. 7E, 9). Boundary between terminal segment and subterminal segment clear, latter length about 2.4 times as former, groove for $\mathrm{G} 2$ in ventral surface, G2 destroyed during dissection (Fig. 9).

Etymology. The species is named after the type locality, Jinxiu Yao Autonomous County, Laibin City, Guangxi Zhuang Autonomous Region.

Distribution. The new species is known only from the type locality presently, Jinxiu Yao Autonomous County, Laibin City, Guangxi Zhuang Autonomous Region, southern China.

Ecology. The collection site is a small river running behind Tongfu village. The river is mostly surrounded by dwarf mountains and many kinds of fruit trees. The river is approximately 2 meters in width, the water depth is approximately 0.4 meters, the riverbed mainly consists of sand and gravel and the water quality is good.

\section{Remarks.}

Heterochelamon jinxiuense $\mathrm{n}$. sp. can easily be differentiated from its congeners by its distally tapered G1 (Fig. 9, Table 1) (versus widening distally or not tapered distally in congeners), blunt external orbital angle (Fig. 6A, Table 1) (versus triangular or acutely triangular in congeners, except that of $H$. guangxiense which is also blunt), strongly unequal chelipeds in adult males and medium gap when male major chela fingers closed (Fig. 7A, Table 1) (versus strongly unequal in H. tessellatum, H. purpureomanualis and H. yangshuoense, but fingers with very broad and oblong gap when closed; other species unequal with narrow gap when closed). The detailed differences between this new species and congeners are also presented in Table 1.

The new species was collected in 2011, of which the material consisted of five males (one adult and four immature) and one female. The G2 of the only mature male had been destroyed by the time we examined the specimens. We were also unable to find this species in a subsequent collection trip. As of such, the G2 is not described here. 
278

279

280

281

282

283

284

285

286

287

288

289

290

291

292

293

294

295

296

297

298

299

300

301

302

303

304

305

306

307

308

309

310

311

312

313

314

315

316

317

\section{Phylogenetic analyses}

We obtained the mitochondrial 16S rRNA gene molecular data from four species of Heterochelamon for this study. Other sequences used were downloaded from GenBank. To show where these two new species fit within the Asian freshwater crab phylogeny, 60 species of 47 genera in the family Potamidae Ortmann, 1896, were used (Table 2). The trees were constructed via the BI and ML methods and showed a high degree of consistency, and the topological structure was determined from BI with support values from both methods (Fig. 10). The phylogenetic results support the recognition of the two new Heterochelamon species, $H$. tessellatum and $H$. castanea cluster with the two new species to form an independent branch in the "China-East Asia Islands" clade (Shih, Yeo \& Ng, 2009). It is possible that the two new species are in sister relationship. H. castanea is most closely related to the two new species in the two known congeneric species available for the molecular phylogenetic analysis.

\section{Discussion}

The genetic analysis supports the recognition of four species of Heterochelamon which can also be differentiated morphologically. These four species form a monophyletic group with relatively high support values. Due to the lack of specimens of the other three species of Heterochelamon, we were unable to obtain their molecular data for analysis and therefore unable to determine the phylogenetic relationships of these species with the above four species.

Phylogenetically, it is possible that Heterochelamon huidongense $\mathrm{n}$. $\mathrm{sp}$. is more closely related to Heterochelamon jinxiuense n. sp. than any other congener (Fig.10). However, the two can be immediately separated by the following characters: the epibranchial tooth of $H$. huidongense is very sharp (versus blunt in $H$. jinxiuense) (Figs. 1A and 6A), adult male chelipeds of $H$. huidongense unequal (versus strongly unequal in $H$. jinxiuense) (Figs. 1A and 6A), G1 terminal segment of $H$. huidongense bent in middle and not tapered distally (versus straight and tapered distally in H. jinxiuense) (Figs. 4A and 9A). The detailed differences among the two new species and other congeneric species are also presented in Table 1.

Türkay \& Dai (1997) established Heterochelamon with Potamon (Geothelphusa) pupureomanualis $\mathrm{Wu}, 1934$ as a type species. However, the real identity of the specimens examined by Türkay \& Dai (1997) is questionable, because their specimens are different from the original description by $\mathrm{Wu}$ (1934) in the following particulars, although we could not examine type material or topotypic material from Luocheng Country, Guangxi Zhuang Autonomous Region: the epibranchial tooth is very sharp in the type material (Wu, 1934) versus blunt in the specimens examined by Türkay \& Dai (1997), and the G1 terminal segment has a bent tip in the type material $(\mathrm{Wu}, 1934)$ versus straight terminal segment in the specimens examined by Türkay \& Dai (1997) (see also Table 1). Furthermore, the specimens examined by Türkay \& Dai (1997) were said to be collected from Xiushui County, Guangxi. The locality record seems to be incorrect, because Xiushui County is in Jiangxi, not in Guangxi. Dai (1999) corrected the locality of the specimens studied by Türkay \& Dai (1997) to Xiuren County, 
318 Guangxi, and we believe that this is correct locality. We concur with Naruse, Zhu \& Zhou (2013)

319 that the specimens referred to H. pupureomanualis by Türkay \& Dai (1997) could actually

320 represent an undescribed species. This matter can only to be addressed when the specimens can

321 be re-examined.

322 With a few exceptions, most Chinese freshwater crab genera have restricted distributional

323 ranges. The geographical distribution pattern of many freshwater crabs is caused by geographical

324 isolation, which is due to the limited dispersal abilities of freshwater crabs and low fertility (Yeo

325 et al., 2008; Ji et al., 2016; Jia et al., 2018). The distribution pattern of freshwater crabs in

326 mainland China is closely related to the regional differentiation of China's natural geographical

327 environment. Heterochelamon has been reported to be mainly distributed in northern Guangxi

328 (Türkay \& Dai, 1997; Naruse, Zhu \& Zhou, 2013). Noteworthy in this paper is that we describe a

329 new species assigned to the genus from southern Guangdong, which is not in the known range of

330 the genus, suggesting that it has a wider distributional pattern than previously thought. That

331 being said, the distribution of Heterochelamon is still within the Huanan freshwater

332 zoogeographical province, which mainly consists of Guangxi, Guangdong and Hainan (Huang,

333 Ebach \& Ahyong, 2020). Within this zoogeographical province, there are relatively few abiotic

334 factors such has high mountains and rivers that may obstruct the dispersal of freshwater crabs.

335 We therefore believe that there are other new species of Heterochelamon in this zoogeographical 336 province.

337

338

339

340

341

342

343

344

345

346

347

348

\section{Conclusions}

This study describes two new species of freshwater potamid crabs, referred to the genus

Heterochelamon. We obtained sequence data of the mitochondrial 16S rRNA gene from the two new species and two other congeneric species for genetic analysis. The analysis supports the recognition of the two new species and the monophyly of the genus. The known distribution of this genus has been heretofore restricted to northern Guangxi, but our study now shows that the genus also occurs in southern Guangdong.

\section{Acknowledgments}

We thank Ya-Nan Zhang, Meng-Jun Zhao and Xin-Nan Jia for their help with the molecular experiments and phylogenetic tree. Thanks also to Chao Huang, who provided the image of figure $5 \mathrm{C}$. We are most grateful to Jia-Ming Tian, who provided us with specimens and led us

350 during our second collection. Finally, we give a special thanks to dear Tomoyuki Komai and 351 other two anonymous reviewers for greatly improving our manuscript.

352

\section{References}

354

355

Castresana J. 2000. Selection of conserved blocks from multiple alignments for their use in phylogenetic analysis. Molecular Biology and Evolution 17(4):540-552 DOI 10.1093/oxfordjournals.molbev.a026334. 
Chu KL, Ma XP, Zhang ZW, Wang PF, Lü LN, Zhao Q, Sun HY. 2018. A checklist for the classification and distribution of China's freshwater crabs. Biodiversity Science 26 (3):274282 DOI 10.17520/biods.2018062 [in Chinese with English summary].

Chu KL, Wang PF, Sun HY. 2018. A new genus and species of primary freshwater crab and a new species of Artopotamon Dai \& Chen, 1985 (Crustacea, Brachyura, Potamidae) from western Yunnan, China. Zootaxa 4422:115 DOI 10.11646/zootaxa.4422.1.7.

Dai AY. 1999. Fauna Sinica (Arthropoda. Crustacea. Malacostraca. Decapoda. Parathelphusicae. Potamidae). Beijing: Science Press [in Chinese with English summary].

Davie PJF, Guinot D, Ng PKL. 2015. Anatomy and functional morphology of Brachyura. In: Castro P, Davie PJF, Guinot D, Schram FR, von Vaupel Klein JC (Eds) Treatise on Zoology - Anatomy, Taxonomy, Biology. The Crustacea Volume 9C-I. Decapoda: Brachyura, 1049-1130 DOI 10.1163/9789004190832.

Huang C. 2018. Revision of Yarepotamon Dai \& Türkay, 1997 (Brachyura: Potamidae), freshwater crabs endemic to southern China, with descriptions of two new genera and four new species. Journal of Crustacean Biology 38:173-189 DOI 10.1093/ jcbiol/rux120.

Huang C, Ahyong ST, Shih H-T. 2017. Cantopotamon, A New Genus of Freshwater Crabs from Guangdong, China, with Descriptions of Four New Species (Crustacea: Decapoda: Brachyura: Potamidae). Zoological Studies 56:41 DOI 10.6620/ZS.2017.56-41.

Huang C, Ebach MC, Ahyong ST. 2020. Bioregionalisation of the freshwater zoogeographical areas of mainland China. Zootaxa 4742(2):271-298 DOI 10.11646/zootaxa.4742.2.3.

Huang C, Huang SZ, Shen ZX. 2020. A new long-legged terrestrial freshwater crab, Calcipotamon puglabrum gen. nov. et sp. nov. (Crustacea: Decapoda: Potamidae), from Hainan Island, China. Zootaxa 4766(3):447-456 DOI 10.11646/zootaxa.4766.3.4

Huang C, Mao SY, Huang JR. 2014. Two new potamid crabs, Yuexipotamon arcophallus new genus, new species and Minutomon shanweiense new genus, new species, (Crustacea: Decapoda: Brachyura: Potamidae) from southern China. Zootaxa 3764(4):455-466 DOI 10.11646/zootaxa.3764.4.5.

Huang C, Shih H-T, Ahyong ST. 2018. Two new genera and two new species of narrow-range freshwater crabs from Guangdong, China (Decapoda: Brachyura: Potamidae). Journal of Crustacean Biology 38(5):614-624 DOI 10.1093/jcbiol/ruy050.

Huang C, Shih H-T, Mao SY. 2016. Yuebeipotamon calciatile, a new genus and new species of freshwater crab from southern China (Crustacea, Decapoda, Brachyura, Potamidae). ZooKeys 615:61-72 DOI 10.3897/ zookeys.615.9964.

Huang C, Shih H-T, Ng PKL. 2017. A new genus and new species of Potamidea (Crustacea: Decapoda: Brachyura: Potamoidae), the first stygomorphic cave crab known from China and East Asia. Zootaxa 4232(1):071-084 DOI 10.11646/zootaxa.4232.1.5.

Huang C, Wong KC, Ahyong ST. 2018. The freshwater crabs of Macau, with the description of a new species of Nanhaipotamon Bott, 1968 and the re-description of Nanhaipotamon wupingense Cheng, Yang, Zhong \& Li, 2003 (Crustacea, Decapoda, Potamidae). ZooKeys 810:91-111 DOI 10.3897/zookeys.810.30726. 
397

398

399

400

401

402

403

404

405

406

407

408

409

410

411

412

413

414

415

416

417

418

419

420

421

422

423

424

425

426

427

428

429

430

431

432

433

434

435

436

Ji YK, Sun YF, Gao W, Chu KL, Wang RC, Zhao Q, Sun HY. 2016. Out of the sichuan basin: rapid species diversification of the freshwater crabs in Sinopotamon (Decapoda: Brachyura: Potamidae) endemic to China. Molecular Phylogenetics and Evolution 100:8094 DOI 10.1016/j.ympev.2016.04.003.

Jia XN, Xu SX, Bai J, Wang YF, Nie ZH, Zhu CC, Wang Y, Cai YX, Zou JX, Zhou XM. 2018. The complete mitochondrial genome of Somanniathelphusa boyangensis and phylogenetic analysis of Genus Somanniathelphusa (Crustacea: Decapoda: Parathelphusidae). PLoS ONE 13(2): e0192601 DOI 10.1371/journal.pone.0192601.

Kumar S, Stecher G, Li M, Knyaz C, Tamura K. 2018. MEGA X: Molecular evolutionary genetics analysis across computing platforms. Molecular Biology and Evolution 35:15471549.

Nakamura T, Yamada KD, Tomii K, Katoh K, Hancock J. 2018. Parallelization of MAFFT for large-scale multiple sequence alignments. Bioinformatics 34(14):2490-2492 DOI 10.1093/bioinformatics/bty 121.

Naruse T, Zhu CC, Zhou XM. 2013. Two new species of freshwater crabs of the genus Heterochelamon Türkay \& Dai, 1997 (Crustacea: Decapoda: Brachyura: Potamidae) from Guangxi Zhuang Autonomous Region, southern China. Zootaxa 3647(4):567-576 DOI 10.11646/zootaxa.3647.4.6.

Ng PKL, Guinot D, Davie PJF. 2008. Systema Brachyurorum: Part 1. An Annotated checklist of extant Brachyuran crabs of the world. Raffles Bulletin of Zoology 17:1-286.

Ng PKL. 2017. Descriptions of two new cavernicolous species of Chinapotamon Dai \& Naiyanetr, 1994 (Crustacea: Brachyura: Potamidae) from China. Crustacean Research 46:1-16 DOI 10.18353/crustacea.46.0_1.

Nylander JAA. 2005. MrModeltest, version 2.2. Program distributed by the author. Evolutionary Biology Centre, Uppsala University, Uppsala, Sweden.

Rambaut A, Suchard MA, Xie D, Drummond AJ. 2014. Tracer v1.6. Available from: http://beast.bio.ed.ac.uk/Tracer Accessed 22 March 2018.

Ronquist F, Teslenko M, van der Mark P, Ayres DL, Darling A, Hohna S. 2012. MrBayes 3.2: Efficient Bayesian phylogenetic inference and model choice across a large model space. Systematic Biology 61:539-542 DOI 10.1093/sysbio/sys029.

Shih H-T, Darren CJY, Ng PKL. 2009. The collision of the Indian plate with Asia: molecular evidence for its impact on the phylogeny of freshwater crabs (Brachyura: Potamidae). Journal of Biogeography 36:703-719 DOI 10.1111/j.1365-2699.2008.02024.x.

Shih H-T, Do VT. 2014. A new species of Tiwaripotamon Bott, 1970, from northern Vietnam, with notes on T. vietnamicum (Dang \& Ho, 2002) and T. edostilus Ng \& Yeo, 2001 (Crustacea, Brachyura, Potamidae). Zootaxa 3764(1):026-038 DOI 10.11646/zootaxa.3764.1.2.

Türkay M, Dai AY. 1997. Review of the Chinese freshwater crabs previously placed in the genus Malayopotamon Bott, 1968 (Crustacea: Decapoda: Brachyura: Potamidae). Raffles Bulletin of Zoology 45(2):189-207. 
437 Wang SB, Huang C, Zou JX. 2019. Description of a new species of freshwater crab of the 438 genus Qianguimon Huang, 2018 (Crustacea: Decapoda: Brachyura: Potamidae) from Yulin, 439 Guangxi, southern China. Zoological Studies 58:31 DOI 10.6620/ZS.2019.58-31.

440 Wang SB, Zhou XM, Zou JX. 2019. A new species of freshwater crab of the genus 441 Mediapotamon Türkay \& Dai, 1997 (Crustacea, Decapoda, Brachyura, Potamidae) from 442 Guizhou, China. ZooKeys 873:9-23 DOI 10.3897/zookeys.873.36702.

443 Wu HW. 1934. Enumeration of the river-crabs (Potamonidae) of China, with descriptions of 444 three new species. Sinensia 4:338-352.

445 Yeo DCJ, Ng PKL, Cumberlidge N, Magalhães C, Daniels SR, Campos MR. 2008. Global 446 diversity of crabs (Crustacea: Decapoda: Brachyura) in freshwater. Hydrobiologia 595:275447286.

448 Zhu CC, Naruse T, Zhou XM. 2010. Two new species of freshwater crabs of the genus 449 Sinolapotamon Tai \& Sung, 1975 (Decapoda, Brachyura, Potamidae) from Guangxi Zhuang Autonomous Region, China. Crustaceana 83(2):245-256 DOI 10.1163/001121609X12603430877199. 
Figure 1

Heterochelamon huidongense $\mathrm{n}$. sp. Holotype male $(25.8 \times 23.1 \mathrm{~mm})(\mathrm{NCU}$ MCP 423601).

(A) overall habitus; (B) frontal view of the cephalothorax. Scales $=1 \mathrm{~cm}$. Photo credit: SongBo Wang. 


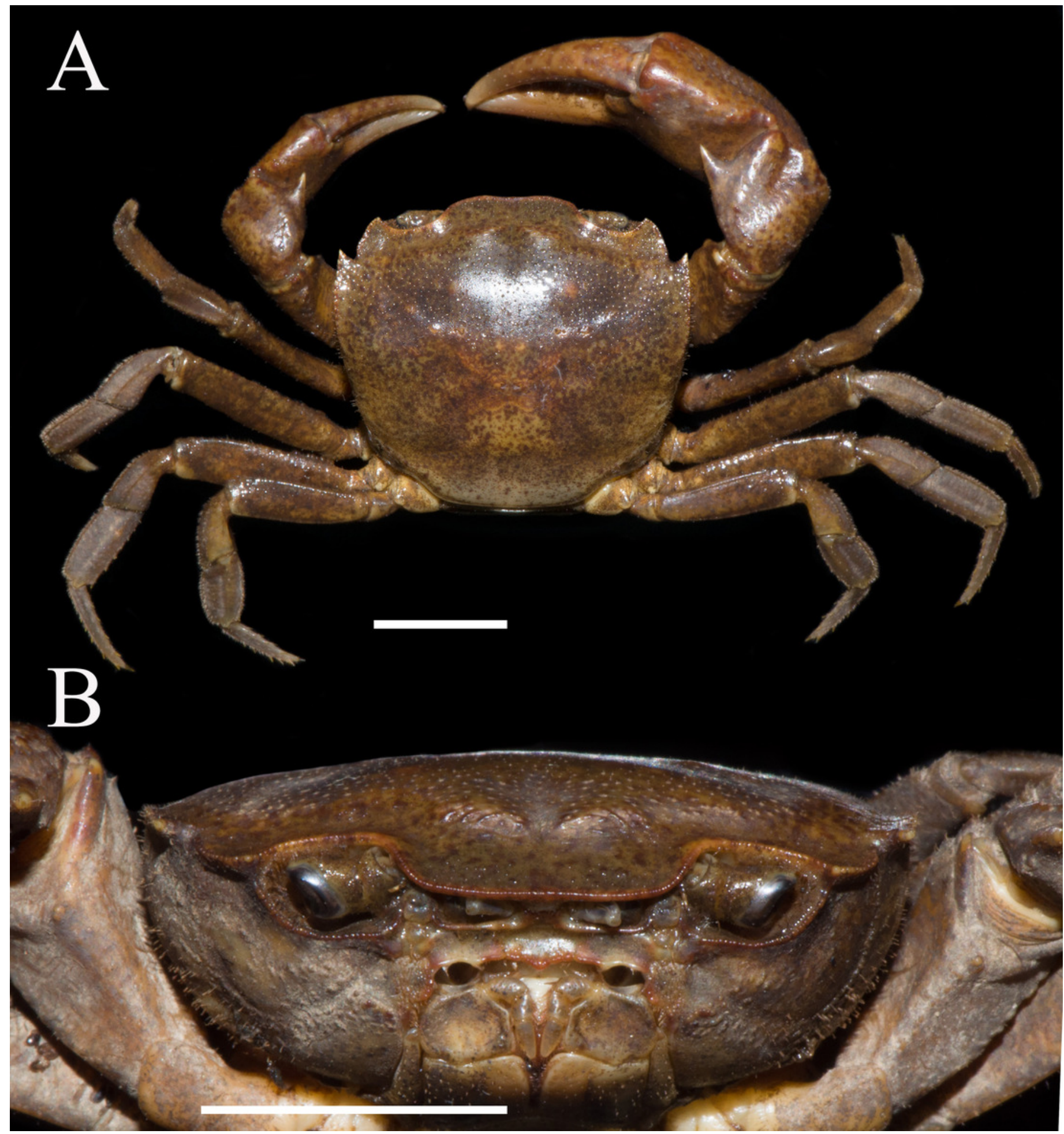


Figure 2

Heterochelamon huidongense $\mathrm{n}$. sp. Holotype male $(25.8 \times 23.1 \mathrm{~mm})(\mathrm{NCU}$ MCP 423601).

(A) outer view of larger cheliped; (B) left third maxilliped; (C) ventral view of anterior thoracic sternum; (D) ventral view of pleon; (E) ventral view of sterno-pleonal cavity with right G1 in situ; (F) right fourth ambulatory leg. Scales $=0.5 \mathrm{~cm}$. Photo credit: Song-Bo Wang. 


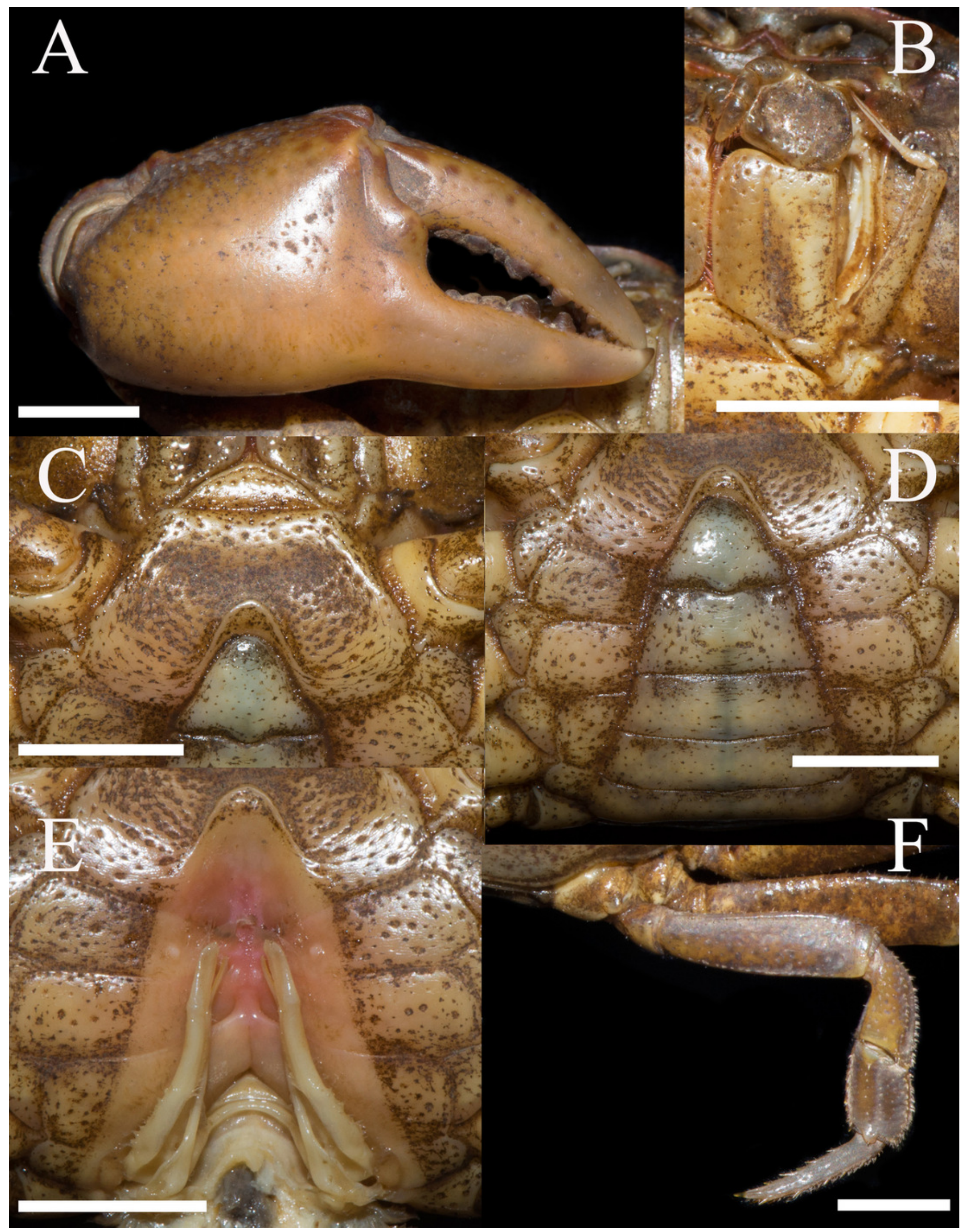


Figure 3

Heterochelamon huidongense $\mathrm{n}$. sp. Paratype female $(26.1 \times 23.5 \mathrm{~mm})$ (NCU MCP 423603).

(A) overall habitus; (B) ventral view of pleon; (C) vulvae. Scales $=1 \mathrm{~cm}$. Photo credit: SongBo Wang. 


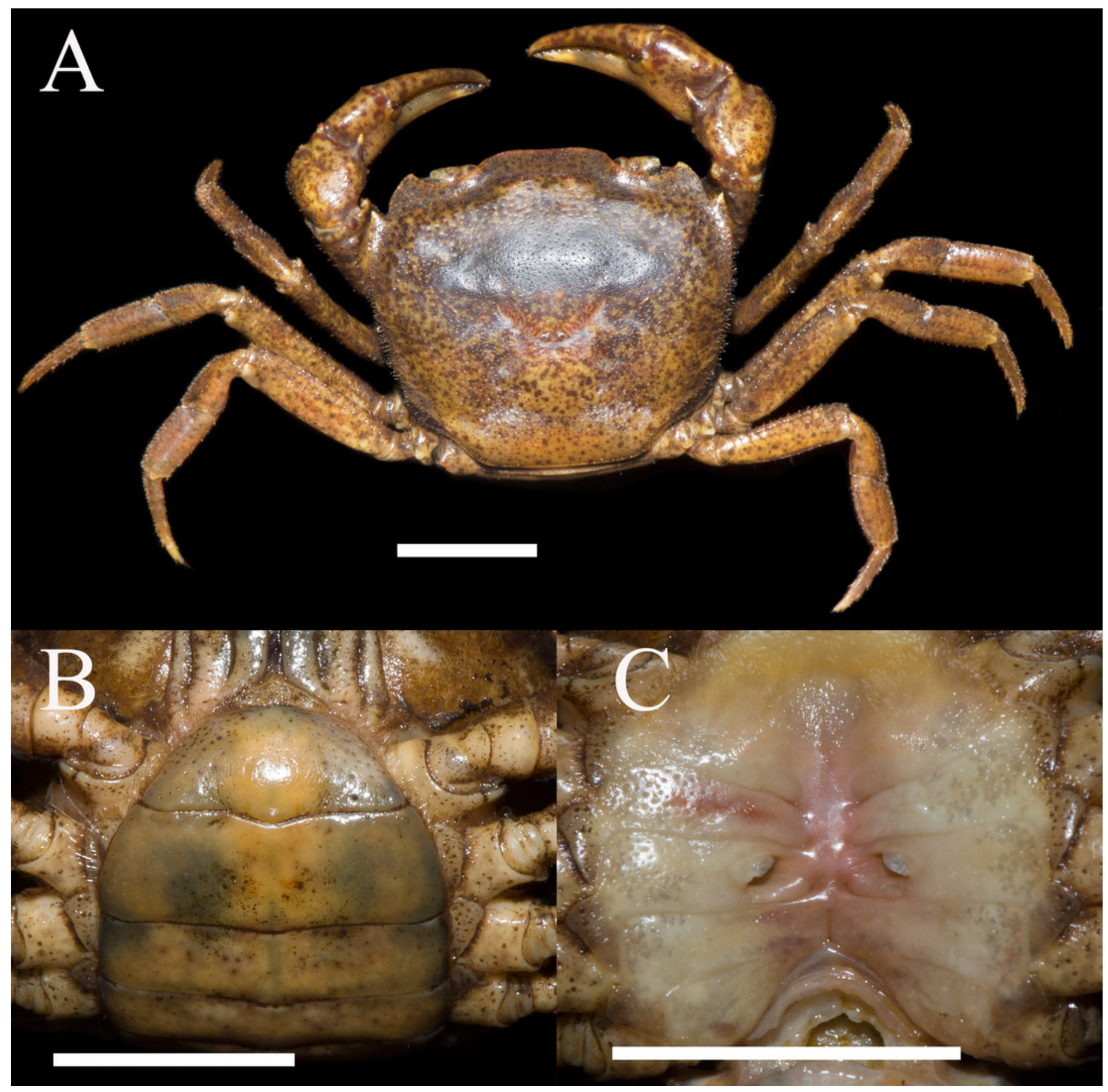


Figure 4

Gonopods of holotype of Heterochelamon huidongense n. sp.

(A) ventral view of the left $\mathrm{Gl}$; (B) ventral view of the terminal segment of left $\mathrm{G1}$; (C) dorsal view of the left $\mathrm{G} 1$; (D) dorsal view of the terminal segment of left $\mathrm{GI}$; $(E)$ ventral view of the left G2. Scales $=1 \mathrm{~mm}$. Photo credit: Song-Bo Wang.
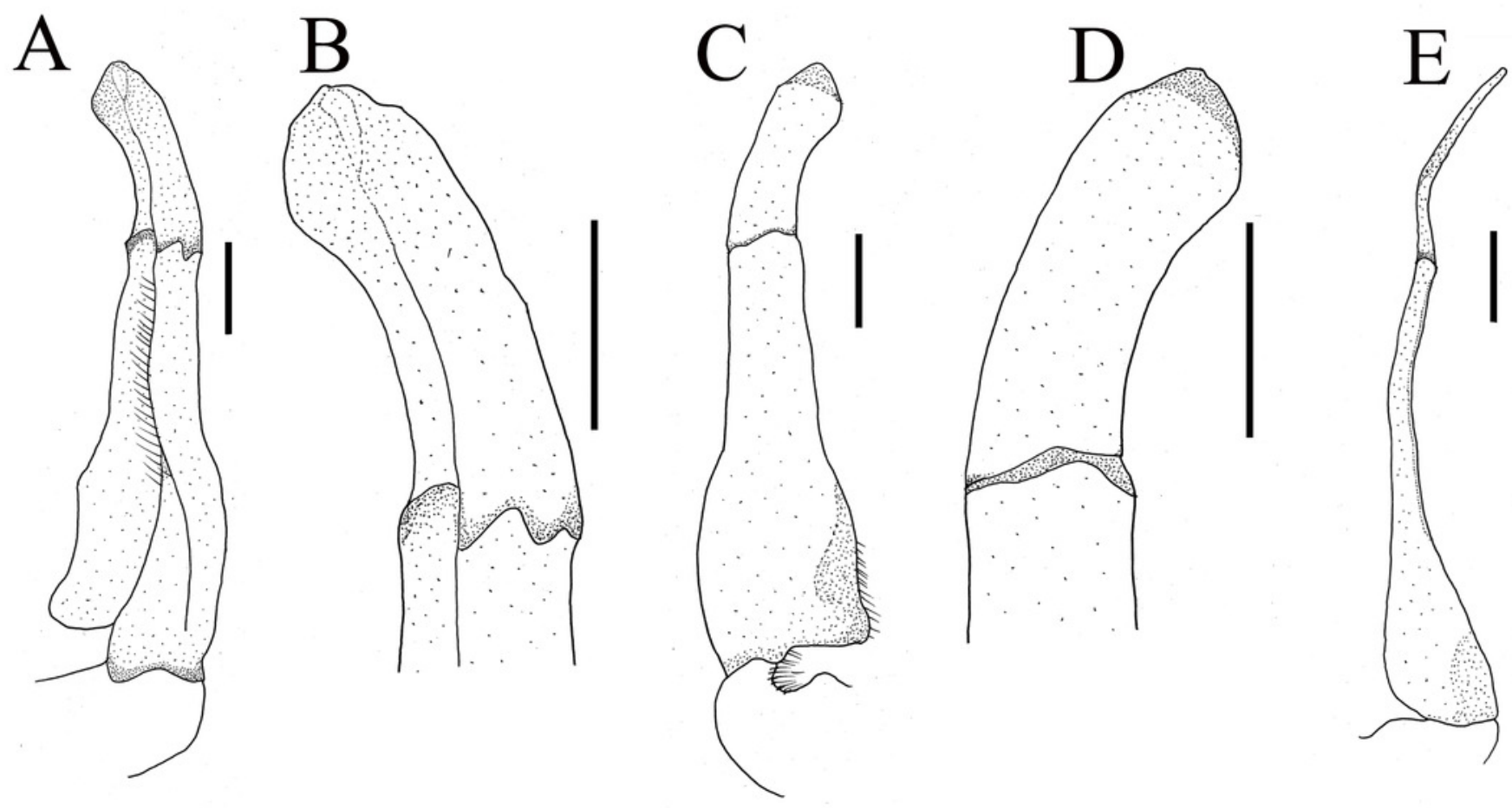


\section{Figure 5}

Habitat Environment of Heterochelamon huidongense n. sp.

(A) Surrounding environment of the collection point; (B) living specimen of $H$. huidongense $n$.

$\mathrm{sp}$. collected with a fish cage; (C) H. huidongense $\mathrm{n}$. sp. in the water; (D) living specimen of

Somanniathelphusa Bott, 1968, collected with a fish cage; (E) collection point. Photo credit:

A, B, D, E from Song-Bo Wang and C from Chao Huang. 


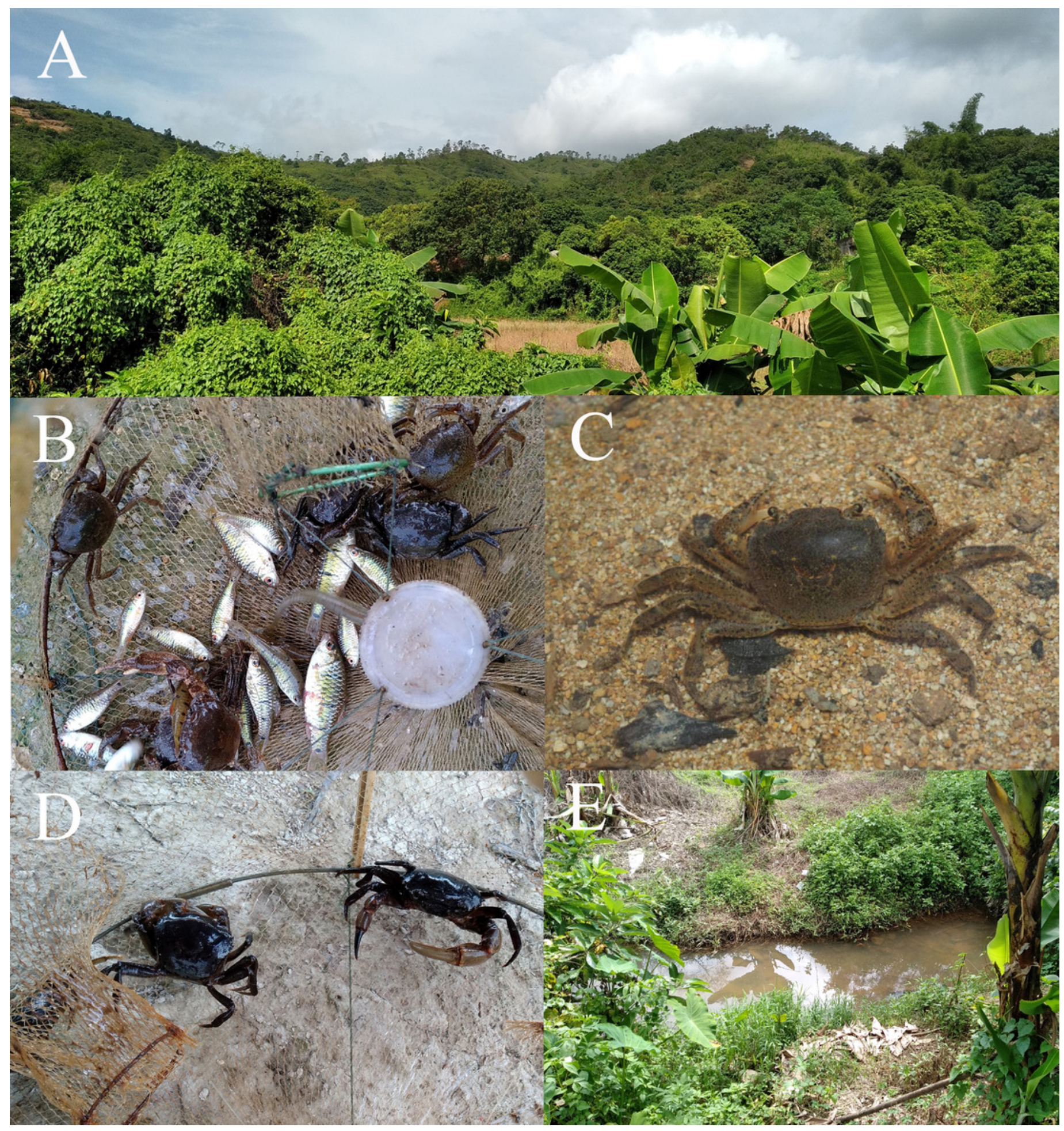


Figure 6

Heterochelamon jinxiuense n. sp. Holotype male $(24.6 \times 19.8$ mm) (NCU MCP 342001).

(A) overall habitus; (B) frontal view of the cephalothorax. Scales $=1 \mathrm{~cm}$. Photo credit: SongBo Wang. 


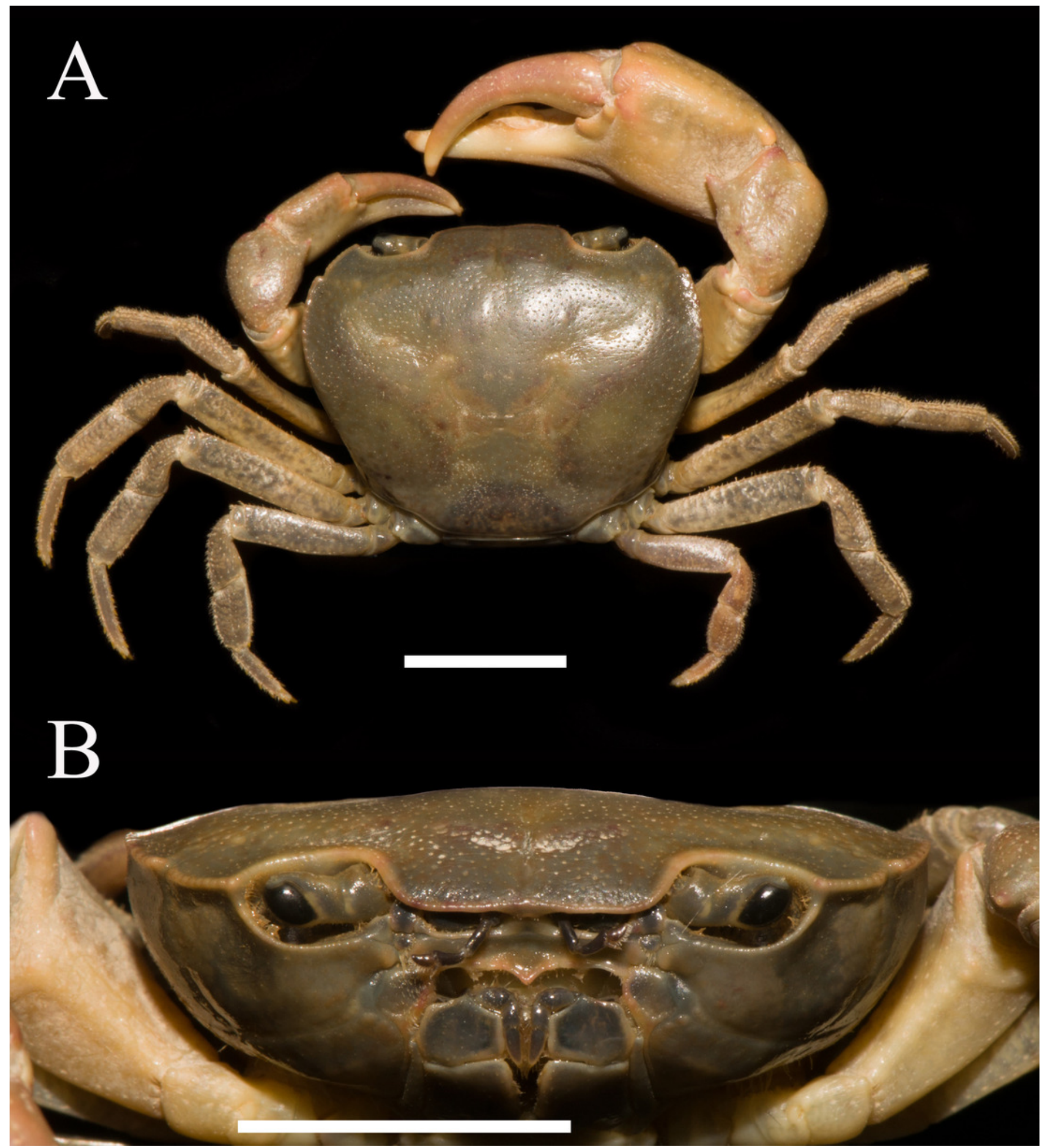




\section{Figure 7}

Heterochelamon jinxiuense n. sp. Holotype male $(24.6 \times 19.8$ mm) (NCU MCP 342001).

(A) outer view of larger cheliped; (B) left third maxilliped; (C) ventral view of anterior thoracic sternum; (D) ventral view of pleon; (E) ventral view of sterno-pleonal cavity with right G1 in situ; (F) right fourth ambulatory leg. Scales $=0.5 \mathrm{~cm}$. Photo credit: Song-Bo Wang. 


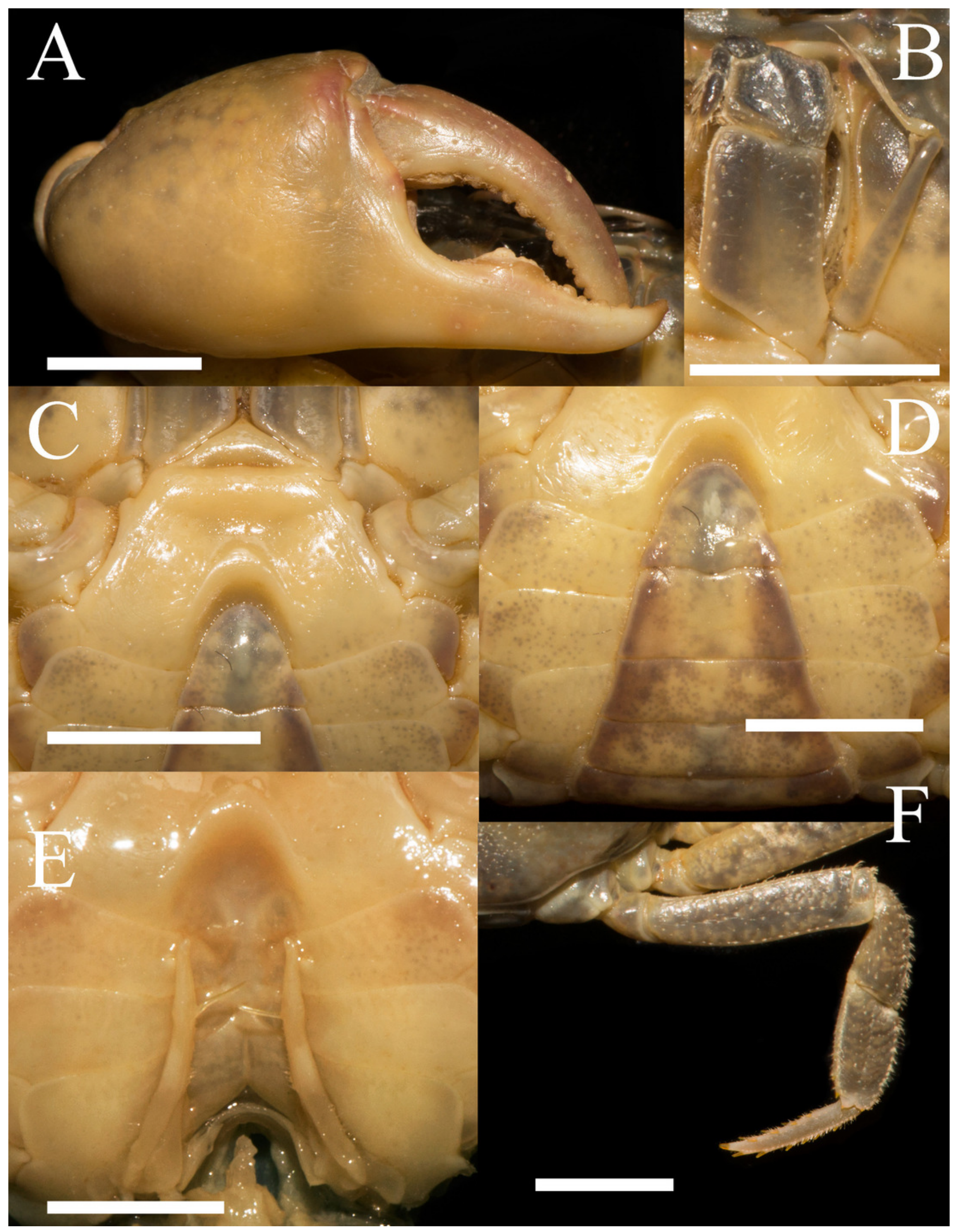


Figure 8

Heterochelamon jinxiuense $\mathrm{n}$. sp. Paratype female $(12.9 \times 10.4 \mathrm{~mm})(\mathrm{NCU}$ MCP 342003).

(A) overall habitus; (B) ventral view of vulvae. Scales $=1 \mathrm{~cm}$. Photo credit: Song-Bo Wang. 


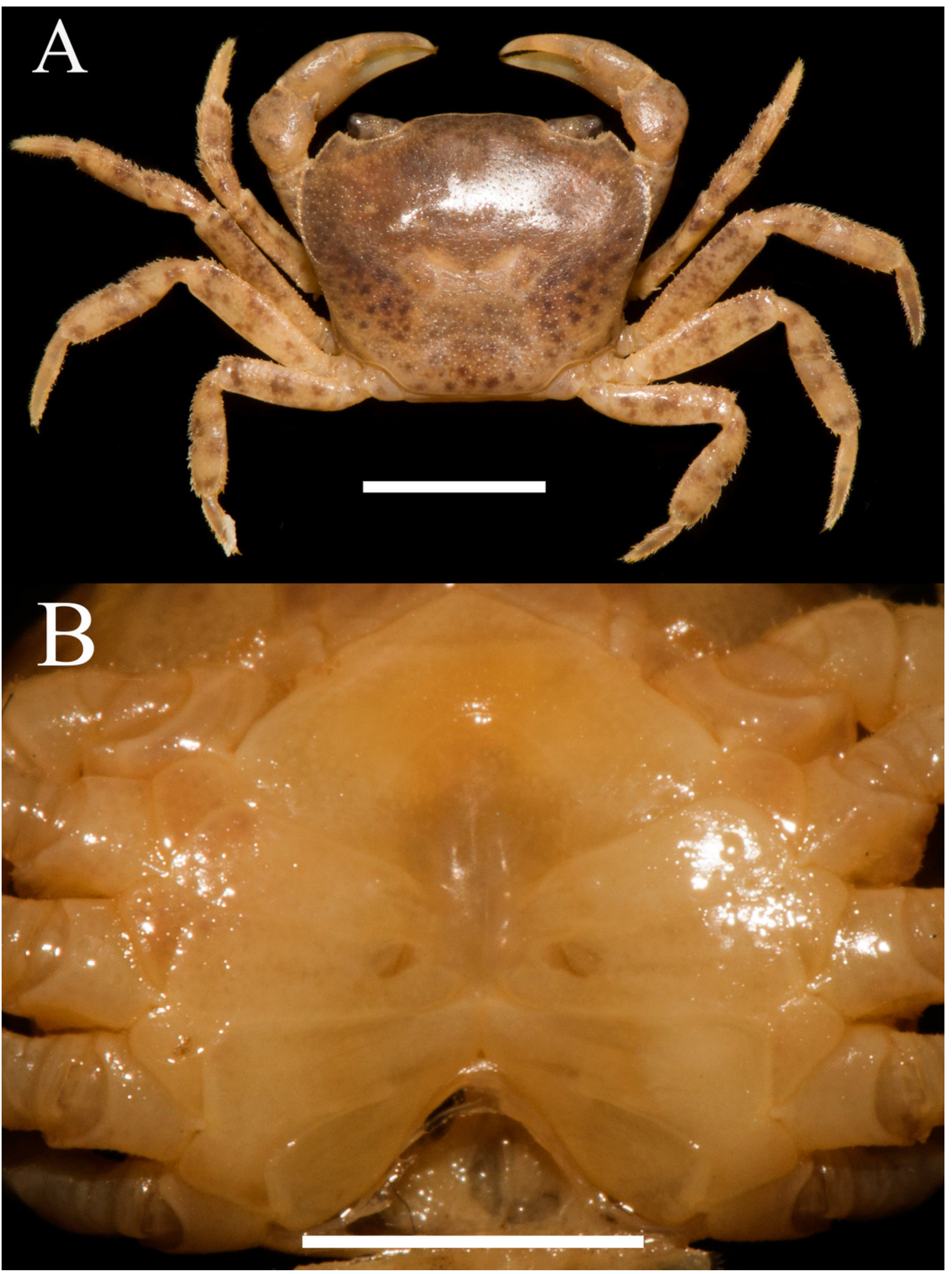


Figure 9

The first gonopods of holotype of Heterochelamon jinxiuense n. sp.

(A) ventral view of the right $\mathrm{Gl}$; (B) ventral view of the terminal segment of right $\mathrm{Gl}$; (C) dorsal view of the right $G 1 ;(D)$ dorsal view of the terminal segment of right $G 1 ;(E)$ side view of the right G1. Scales $=1 \mathrm{~mm}$. Photo credit: Song-Bo Wang.
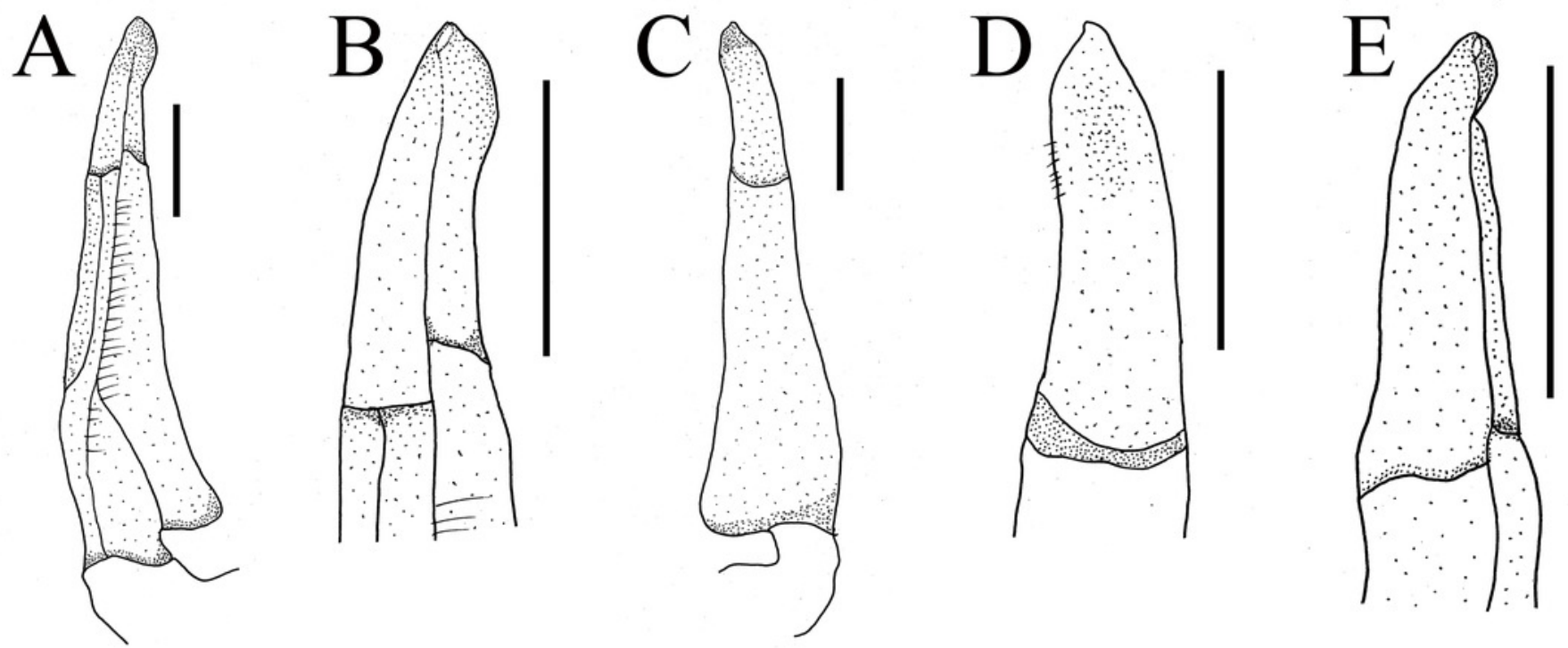
Figure 10

Phylogenetic tree.

Reconstructed base on the 16S rRNA genes of Heterochelamon and some species of Asian

potamids sampled for comparison. Branch lengths and topologies were obtained from $\mathrm{BI}$

analysis. Probability values at the nodes represent support values for $\mathrm{BI}$ and $\mathrm{ML}$. Only values

$>50 \%$ are shown. Photo credit: Song-Bo Wang.

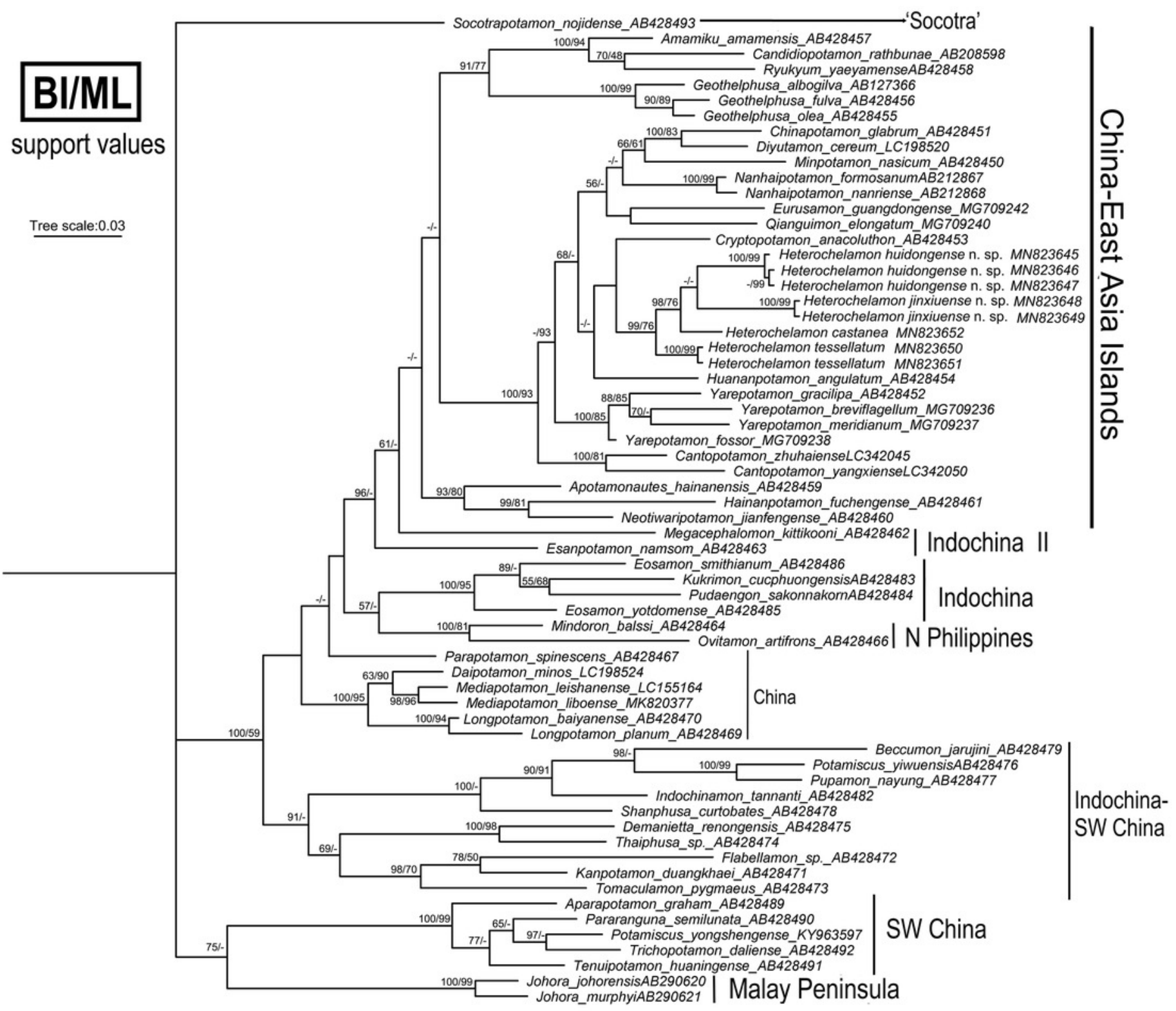




\section{Table 1 (on next page)}

Differences between the species of Heterochelamon Türkay \& Dai, 1997. 


\section{H. huidongense H. jinxiuense H. tessellatum H. castanea}

$H$

H.

H. H. yangshuoense

\section{purpureomanualis $^{1}$ purpureomanualis $^{2}$ guangxiense}

\begin{tabular}{|c|c|c|c|c|c|c|c|c|}
\hline $\begin{array}{l}\text { External } \\
\text { orbital angle }\end{array}$ & $\begin{array}{l}\text { Triangular } \\
\text { (Fig. 1A) }\end{array}$ & Blunt (Fig. 6A) & $\begin{array}{l}\text { Acutely } \\
\text { triangular (cf. } \\
\text { Naruse, Zhu \& } \\
\text { Zhou, 2013: } \\
\text { Fig. 1A) }\end{array}$ & $\begin{array}{l}\text { Triangular (cf. } \\
\text { Naruse, Zhu \& } \\
\text { Zhou, 2013: } \\
\text { Fig. 4A) }\end{array}$ & $\begin{array}{l}\text { Acutely } \\
\text { triangular (cf. } \\
\text { Wu, 1934: Fig. } \\
\text { 2) }\end{array}$ & $\begin{array}{l}\text { Triangular (cf. } \\
\text { Türkay \& Dai, } \\
\text { 1997) }\end{array}$ & $\begin{array}{l}\text { Blunt (cf. } \\
\text { Türkay \& Dai, } \\
\text { 1997) }\end{array}$ & $\begin{array}{l}\text { Triangular (cf. } \\
\text { Türkay \& Dai, } \\
\text { 1997) }\end{array}$ \\
\hline $\begin{array}{l}\text { Epibranchial } \\
\text { tooth }\end{array}$ & $\begin{array}{l}\text { Very sharp, } \\
\text { separated from } \\
\text { external orbital } \\
\text { angle by broad } \\
\text { notch (Fig. 1A) }\end{array}$ & $\begin{array}{l}\text { Blunt, } \\
\text { separated from } \\
\text { external orbital } \\
\text { angle by } \\
\text { narrow notch } \\
\text { (Fig. 6A) }\end{array}$ & $\begin{array}{l}\text { Very sharp, } \\
\text { separated from } \\
\text { external orbital } \\
\text { angle by broad } \\
\text { notch (cf. } \\
\text { Naruse, Zhu \& } \\
\text { Zhou, 2013: } \\
\text { Fig. 1A) }\end{array}$ & $\begin{array}{l}\text { Very sharp, } \\
\text { separated from } \\
\text { external orbital } \\
\text { angle by } \\
\text { narrow notch } \\
\text { (cf. Naruse, } \\
\text { Zhu \& Zhou, } \\
\text { 2013: Fig. 4A) }\end{array}$ & $\begin{array}{l}\text { Very sharp, } \\
\text { separated from } \\
\text { external orbital } \\
\text { angle by } \\
\text { narrow notch } \\
\text { (cf. Wu, 1934: } \\
\text { Fig. 2) }\end{array}$ & $\begin{array}{l}\text { Blunt, } \\
\text { separated from } \\
\text { external orbital } \\
\text { angle by } \\
\text { narrow notch } \\
\text { (cf. Türkay \& } \\
\text { Dai, 1997) }\end{array}$ & $\begin{array}{l}\text { Very sharp, } \\
\text { separated from } \\
\text { external orbital } \\
\text { angle by broad } \\
\text { notch (cf. } \\
\text { Türkay \& Dai, } \\
\text { 1997) }\end{array}$ & $\begin{array}{l}\text { Very sharp, } \\
\text { separated from } \\
\text { external orbital } \\
\text { angle by broad } \\
\text { notch (cf. } \\
\text { Türkay \& Dai, } \\
\text { 1997) }\end{array}$ \\
\hline $\begin{array}{l}\text { Adult male } \\
\text { chelipeds }\end{array}$ & $\begin{array}{l}\text { Unequal (Fig. } \\
\text { 1A) }\end{array}$ & $\begin{array}{l}\text { Strongly } \\
\text { unequal (Fig. } \\
6 \mathrm{~A})\end{array}$ & $\begin{array}{l}\text { Strongly } \\
\text { unequal (cf. } \\
\text { Naruse, Zhu \& } \\
\text { Zhou, 2013: } \\
\text { Fig. 1A) }\end{array}$ & $\begin{array}{l}\text { Unequal (cf. } \\
\text { Naruse, Zhu \& } \\
\text { Zhou, 2013: } \\
\text { Fig. 4A) }\end{array}$ & $\begin{array}{l}\text { Strongly } \\
\text { unequal (cf. } \\
\text { Wu, 1934: Fig. } \\
\text { 2) }\end{array}$ & $\begin{array}{l}\text { Strongly } \\
\text { unequal (cf. } \\
\text { Türkay \& Dai, } \\
\text { 1997) }\end{array}$ & $\begin{array}{l}\text { Unequal (cf. } \\
\text { Türkay \& Dai, } \\
\text { 1997) }\end{array}$ & $\begin{array}{l}\text { Strongly } \\
\text { unequal (cf. } \\
\text { Türkay \& Dai, } \\
\text { 1997) }\end{array}$ \\
\hline $\begin{array}{l}\text { Gap of adult } \\
\text { male major } \\
\text { chela fingers } \\
\text { when closed }\end{array}$ & $\begin{array}{l}\text { Narrow, } \\
\text { wedge-shaped } \\
\text { (Fig. 2A) }\end{array}$ & $\begin{array}{l}\text { Medium, } \\
\text { teardrop- } \\
\text { shaped (Fig. } \\
\text { 7A) }\end{array}$ & $\begin{array}{l}\text { Very broad, } \\
\text { oblong (cf. } \\
\text { Naruse, Zhu \& } \\
\text { Zhou, 2013: } \\
\text { Fig. 2B) }\end{array}$ & $\begin{array}{l}\text { Narrow, } \\
\text { wedge-shaped } \\
\text { (cf. Naruse, } \\
\text { Zhu \& Zhou, } \\
\text { 2013: Fig. 5B) }\end{array}$ & $\begin{array}{l}\text { Very broad, } \\
\text { oblong (cf. } \\
\text { Wu, 1934: Fig. } \\
\text { 2) }\end{array}$ & $\begin{array}{l}\text { Very broad, } \\
\text { oblong (cf. } \\
\text { Türkay \& Dai, } \\
\text { 1997) }\end{array}$ & $\begin{array}{l}\text { Narrow, } \\
\text { wedge-shaped } \\
\text { (cf. Türkay \& } \\
\text { Dai, 1997) }\end{array}$ & $\begin{array}{l}\text { Very broad, } \\
\text { oblong (cf. } \\
\text { Türkay \& Dai, } \\
\text { 1997: fig. 6-2) }\end{array}$ \\
\hline
\end{tabular}




\begin{tabular}{|c|c|c|c|c|c|c|c|c|}
\hline G1 in situ & $\begin{array}{l}\text { Not reaching } \\
\text { sternites } 4 / 5 \\
\text { suture (Fig. } \\
2 \mathrm{E} \text { ) }\end{array}$ & $\begin{array}{l}\text { Reaching } \\
\text { sternites 4/5 } \\
\text { suture (Fig. } \\
8 \mathrm{E} \text { ) }\end{array}$ & $\begin{array}{l}\text { Not reaching } \\
\text { sternites } 4 / 5 \\
\text { suture (cf. } \\
\text { Naruse, Zhu \& } \\
\text { Zhou, 2013: } \\
\text { Fig. 2A) }\end{array}$ & $\begin{array}{l}\text { Reaching } \\
\text { sternites 4/5 } \\
\text { suture (cf. } \\
\text { Naruse, Zhu \& } \\
\text { Zhou, 2013) }\end{array}$ & No information & $\begin{array}{l}\text { Reaching } \\
\text { sternites 4/5 } \\
\text { suture (cf. } \\
\text { Türkay \& Dai, } \\
\text { 1997: fig. 4-3) }\end{array}$ & $\begin{array}{l}\text { Reaching } \\
\text { sternites 4/5 } \\
\text { suture (cf. } \\
\text { Türkay \& Dai, } \\
\text { 1997: fig. 5-3) }\end{array}$ & $\begin{array}{l}\text { Reaching } \\
\text { sternites 4/5 } \\
\text { suture (cf. } \\
\text { Türkay \& Dai, } \\
\text { 1997: fig. 6-4) }\end{array}$ \\
\hline $\begin{array}{l}\text { Terminal } \\
\text { segment of G1 }\end{array}$ & $\begin{array}{l}\text { Flat, bent in } \\
\text { middle, not } \\
\text { tapered } \\
\text { distally, distal } \\
\text { part rounded } \\
\text { (Fig. 4) }\end{array}$ & $\begin{array}{l}\text { Rod-like, } \\
\text { straight, } \\
\text { tapered } \\
\text { distally, distal } \\
\text { part sharp, bent } \\
\text { slightly at } \\
\text { distal (Fig. 9) }\end{array}$ & $\begin{array}{l}\text { Knuckle- } \\
\text { shaped, } \\
\text { strongly bent } \\
\text { proximally, } \\
\text { widening } \\
\text { distally, widest } \\
\text { part more than } \\
\text { twice as wide } \\
\text { as base (cf. } \\
\text { Naruse, Zhu \& } \\
\text { Zhou, 2013: } \\
\text { Fig. 3A) }\end{array}$ & $\begin{array}{l}\text { Rod-like, } \\
\text { straight, not } \\
\text { tapered } \\
\text { distally, distal } \\
\text { part rounded } \\
\text { and bent } \\
\text { slightly (cf. } \\
\text { Naruse, Zhu \& } \\
\text { Zhou, 2013: } \\
\text { Fig. 6A) }\end{array}$ & No information & $\begin{array}{l}\text { Rod-like, } \\
\text { straight, not } \\
\text { tapered } \\
\text { distally, distal } \\
\text { part protruding } \\
\text { slightly in } \\
\text { inner edge (cf. } \\
\text { Türkay \& Dai, } \\
\text { 1997: fig. 4-4) }\end{array}$ & $\begin{array}{l}\text { Rod-like, } \\
\text { slightly bent, } \\
\text { not tapered } \\
\text { distally, distal } \\
\text { part protruding } \\
\text { in inner edge } \\
\text { (cf. Türkay \& } \\
\text { Dai, 1997: fig. } \\
\text { 5-4) }\end{array}$ & $\begin{array}{l}\text { Knuckle- } \\
\text { shaped, } \\
\text { straight, } \\
\text { widening } \\
\text { distally, widest } \\
\text { part more than } \\
\text { twice as wide } \\
\text { as base (cf. } \\
\text { Türkay \& Dai, } \\
\text { 1997: fig. 6-5) }\end{array}$ \\
\hline
\end{tabular}

$1 \quad{ }^{1}$ Recorded by Wu, 1934 from Luocheng County, Guangxi Zhuang Autonomous Region, China.

2 2Recorded by Türkay \& Dai, 1997 cf. Wu, 1934 from Xiuren County, Guangxi Zhuang Autonomous Region, China. 


\section{Table 2 (on next page)}

GenBank accession number of the species used for phylogenetic analysis.

The $16 \mathrm{~S}$ rRNA gene of 60 species belonging to 47 genera of the family Potamidae. 


\section{Species}

Heterochelamon huidongense $\mathrm{n}$. sp.

Heterochelamon huidongense $\mathrm{n}$. $\mathrm{sp}$.

Heterochelamon huidongense $\mathrm{n} . \mathrm{sp}$.

Heterochelamon jinxiuense $\mathrm{n}$. sp.

Heterochelamon jinxiuense $\mathrm{n}$. sp.

Heterochelamon tessellatum Naruse, Zhu \& Zhou, 2013

Heterochelamon tessellatum Naruse, Zhu \& Zhou, 2013

Heterochelamon castanea Naruse, Zhu \& Zhou, 2013

Amamiku amamense (Minei, 1973)

Aparapotamon grahami (Rathbun, 1929)

Apotamonautes hainanensis (Parisi, 1916)

Beccumon jarujini (Ng \& Naiyanetr, 1993)

Candidiopotamon rathbunae (De Man, 1914)

Cantopotamon yangxiense Chao, Ahyong \&

Shih, 2017

Cantopotamon zhuhaiense Chao, Ahyong \&

Shih, 2017

Chinapotamon glabrum (Dai, Song, Li \&

Liang, 1980)

Cryptopotamon anacoluthon (Kemp, 1918)

Daipotamon minos $\mathrm{Ng} \&$ Trontelj

Demanietta renongensis (Rathbun, 1905)

Diyutamon cereum Huang, Shih \& Ng

Eosamon smithianum (Kemp, 1923)

Eosamon yotdomense (Naiyanetr, 1984)

Esanpotamon namsom Naiyanetr \& Ng, 1997

Eurusanm guangdongense Huang, 2018

Flabellamon sp.

Geothelphusa albogilva Shy, Ng \& Yu, 1994 NCHUZOOL

Geothelphusa marginata fulva Naruse, Shokita NCHUZOOL 13124

\& Shy, 2004

Geothelphusa oleaShy, Ng \& Yu, 1994

Hainanpotamon fuchengense Dai, 1995

Huananpotamon angulatum (Dai \& Lin, 1979)

Indochinamon tannanti (Rathbun, 1904)

Johora johorensis (Roux, 1936)
Museum
Catalogue No.

NCU MCP 423604

NCU MCP 423605

NCU MCP 423606

NCU MCP 342004

NCU MCP 342005

NCU MCP 153601

NCU MCP 153602

NCU MCP 341901

NCHUZOOL 13125

ZRC YCM 0334(II)

ZRC

ZRC 1991.1865

(paratype)

NCHUZOOL

SYSBM 001564

SYSBM 001439

CAS CB

NCHUZOOL 13122

ZRC 1996.1045

ZRC 1998.146

SYSBM

ZRC

ZRC 1991.1851

ZRC 1997.776

(paratype)

SYSBM 001408

ZRC

NCHUZOOL 13123

NCHUZOOL 13128

$\mathrm{ZRC}$

ZRC 1998.264

ZRC 1990.576

\section{Locality}

GenBank

No.

Guangdong, China MN823645

Guangdong, China MN823646

Guangdong, China MN823647

Guangdong, China MN823648

Guangdong, China MN823649

Guangxi, China MN823650

Guangxi, China MN823651

Guangxi, China MN823652

Amami, the

AB428457

Ryukyus

Yunnan, China AB428489

Hainan, China AB428459

Chiangma, $\quad$ AB428479

Thailand

Nantou, Taiwan AB208598

Guangdong, China LC342050

Guangdong, China LC342045

Guangxi, China $\quad$ AB428451

Hong Kong

AB428453

Guizhou, China LC198524

Ranong, Thailand AB428475

Guizhou, China LC198520

Chantaburi, AB428486

Thailand

Ubon Ratchathani, AB428485

Thailand

Udon Thani, $\quad$ AB428463

Thailand

Guangxi, China MG709242

Mae Sot, Thailand AB428472

Pingtung, Taiwan AB127366

AB428456

Ryukyus

Taichung, Taiwan AB428455

Hainan, China AB428461

Fujian, China $\quad$ AB428454

Yunnan, China AB428482

Gunung Pulai, AB290620 


\begin{tabular}{|c|c|c|c|}
\hline & & Johor, Malaysia & \\
\hline Johora murphyi $\mathrm{Ng}, 1986$ & ZRC 2001.2267 & $\begin{array}{l}\text { Kota Tinggi, } \\
\text { Johor, Malaysia }\end{array}$ & AB290621 \\
\hline $\begin{array}{l}\text { Kanpotamon duangkhaei Ng \& Naiyanetr, } \\
1993\end{array}$ & $\mathrm{ZRC}$ & $\begin{array}{l}\text { Kanchanaburi, } \\
\text { Thailand }\end{array}$ & AB428471 \\
\hline Kukrimon cucphuongense (Dang, 1975) & $\begin{array}{l}\text { ZRC NHH9729 } \\
160997\end{array}$ & $\begin{array}{l}\text { Ninh Binh, } \\
\text { Vietnam }\end{array}$ & AB428483 \\
\hline Longpotamon baiyanense Ng \& Dai, 1997 & ZRC & Hunan, China & AB428470 \\
\hline Longpotamon planum Dai, 1992 & ZRC 1998.1178 & Anhui, China & AB428469 \\
\hline Mediapotamon leishanense Dai, 1995 & SYSBM 001094 & Guizhou, China & LC155164 \\
\hline $\begin{array}{l}\text { Mediapotamon liboense Wang, Zhou \& Zou, } \\
2019\end{array}$ & NCU MCP 343004 & Guizhou, China & MK820377 \\
\hline $\begin{array}{l}\text { Megacephalomon kittikooni (Yeo \& } \\
\text { Naiyanetr, 1999) }\end{array}$ & $\begin{array}{l}\text { ZRC } 1998.22 \\
\text { (holotype) }\end{array}$ & $\begin{array}{l}\text { Xieng Khuang, } \\
\text { Laos }\end{array}$ & AB428462 \\
\hline Mindoron balssi (Bott, 1968) & ZRC & $\begin{array}{l}\text { Mindoro, the } \\
\text { Philippines }\end{array}$ & AB428464 \\
\hline Minpotamon nasicum (Dai \& Chen, 1979) & NCHUZOOL 13121 & Fujian, China & AB428450 \\
\hline Nanhaipotamon formosensis (Parisi, 1916) & NCHUZOOL 13144 & Tainan, Taiwan & AB212867 \\
\hline Nanhaipotamon nanriense Dai, 1997 & CAS CB05103 & Fujian, China & AB212868 \\
\hline $\begin{array}{l}\text { Neotiwaripotamon jianfengense Dai \& } \\
\text { Naiyanetr, } 1994\end{array}$ & NCHUZOOL 13127 & Hainan, China & AB428460 \\
\hline Ovitamon artifrons (Bürger, 1894) & ZRC & $\begin{array}{l}\text { Luzon, the } \\
\text { Philippines }\end{array}$ & AB428466 \\
\hline Parapotamon spinescens (Calman, 1905) & NCU MCP & Yunnan, China & AB428467 \\
\hline Pararanguna semilunatum Dai \& Chen, 1985 & ZRC & Yunnan, China & AB428490 \\
\hline Potamiscus yiwuensis Dai \& Cai, 1998 & ZRC & Yunnan, China & AB428476 \\
\hline Potamiscus yongshengense Dai \& Chen, 1985 & NNU15 & Yunnan, China & KY963597 \\
\hline $\begin{array}{l}\text { Pudaengon sakonnakorn Ng \& Naiyanetr, } \\
1995\end{array}$ & ZRC & Thailand & AB428484 \\
\hline Pupamon nayung (Naiyanetr, 1993) & $\begin{array}{l}\text { ZRC } 1995.558 \\
\text { (paratype) }\end{array}$ & $\begin{array}{l}\text { Udon Thani, } \\
\text { Thailand }\end{array}$ & AB428477 \\
\hline Qianguimon elongatum Huang, 2018 & SYSBM 001424 & \multicolumn{2}{|c|}{ Guangdong, China MG709240 } \\
\hline Ryukyum yaeyamense (Minei, 1973) & NCHUZOOL 13126 & $\begin{array}{l}\text { Iriomote, the } \\
\text { Ryukyus }\end{array}$ & AB428458 \\
\hline Shanphusa curtobates (Kemp, 1918) & NRM 13920 & $\begin{array}{l}\text { Taunggyi, Shan } \\
\text { State, Myanmar }\end{array}$ & AB428478 \\
\hline $\begin{array}{l}\text { Socotrapotamon nojidensis Apel \& Brandis, } \\
2000\end{array}$ & ZRC 2000.2232 & Socotra, Yemen & AB428493 \\
\hline Tenuipotamon huaningense Dai \& Bo, 1994 & CAS CB05175 & Yunnan, China & AB428491 \\
\hline Thaiphusa sp. & ZRC 1997.656 & Thailand & AB428474 \\
\hline Tomaculamon pygmaeus Yeo \& Ng, 1997 & $\begin{array}{l}\text { ZRC 1997.326-330 } \\
\text { (paratype) }\end{array}$ & $\begin{array}{l}\text { Phitsanulok, } \\
\text { Thailand }\end{array}$ & AB428473 \\
\hline Trichopotamon daliense Dai \& Chen, 1985 & NCHUZOOL 13130 & Yunnan, China & AB428492 \\
\hline Yarepotamon breviflagellum Huang, 2018 & SYSBM 001442 & \multicolumn{2}{|c|}{ Guangdong, China MG709236 } \\
\hline Yarepotamon fossor Huang, 2018 & SYSBM 001417 & Guangxi, China & MG709238 \\
\hline
\end{tabular}


Yarepotamon gracilipa (Dai, Song, Li \& $\quad$ ZRC $\quad$ Guangxi, China AB428452

Liang, 1980)

Yarepotamon meridianum Huang, $2018 \quad$ SYSBM $001581 \quad$ Guangdong, China MG709237

1 CAS CB, Chinese Academy of Sciences, Beijing, China; NCHUZOOL, Zoological Collections

2 of the Department of Life Science, National Chung Hsing University, Taichung, Taiwan; NCU

3 MCP, Department of Parasitology of the Medical College of Nanchang University, Jiangxi,

4 China; NNU, College of Life Sciences, Nanjing Normal University, Nanjing, China; NRM,

5 Swedish Museum of Natural History, Stockholm, Sweden; SYSBM, Sun Yat-sen Museum of

6 Biology, Sun Yat-Sen University, Guangzhou, China; ZRC, Zoological Reference Collection of

7 the Raffles Museum of Biodiversity Research, National University of Singapore, Singapore. 